Maria JOKA

Białystok

\title{
MODYFIKACJE PORÓWNAŃ UTARTYCH I INDYWIDUALNYCH W TWÓRCZOŚCI JANA PARANDOWSKIEGO
}

\section{Schemat porównania}

W badaniach wykorzystuję ustalony przez Františka Čerm $\left\langle\mathrm{ka}^{1}{ }^{\text {schemat }}\right.$ porównania, który we wzorowej postaci funkcjonuje jako klarowne, proste, o stałych elementach zdanie. Składają się nań: comparandum $(\mathrm{Cd})$ - przedmiot lub zjawisko porównywane, relator $(\mathrm{R})$ - czasownik o szerokiej wartości kategorialnej, np. być, mieć, wyglądá́, czuć się, comparator (c) - łącznik porównania, tertium comparationis $(\mathrm{Tc})$ - określenie, na czym polega podobieństwo, comparatum (Ct) - człon porównujący, np. Usta (Cd) miał (R) czerwone (Tc) jak (c) pęknięte jabłko granatu. $(\mathrm{Ct})(\mathrm{M} \mathrm{134})^{2}$. Koniecznym elementem porównania jest comparatum, pozostałe składniki mogą ulec elipsie ${ }^{3}$. Przedmiotem niniejszego opracowania jest opis porównań, w skład których wchodzi comparator wraz z jego oryginalnymi wariantami ${ }^{4}$.

\section{Modyfikacje}

Znanym zjawiskiem językowym jest modyfikacja wyrażeń, zwrotów wcześniej wytworzonych. Przekształceniom mogą być poddawane frazeologizmy, a także ustne, bądź pisemne wypowiedzi indywidualne, zarówno obce jak i własne ${ }^{5}$.

\footnotetext{
${ }^{1}$ Česká přirovnání, w: Slovnik české frazeologie a idiomatiky. Přirovnání, Praha 1983 - cyt. za: Z. Leszczyński, Doświadczenie tekstów sakralnych odbite $w$ obiegowych porównaniach, „Łódzkie Studia Teologiczne” 3 (1994), s. 152.

${ }^{2}$ Skróty zamieszczone w nawiasach oznaczają źródła - tytuły i strony - cytowanych fragmentów tekstów i są rozwiązane na końcu artykułu.

3 Z. Leszczyński, op. cit., s. 152-154.

${ }^{4}$ Szerzej o oryginalnych łącznikach w: M. Joka, Indywidualne warianty comparatora $w$ twórczości Jana Parandowskiego, „Roczniki Humanistyczne”, t. XLIX-L, z. 6, Lublin 2001-2002, s. 145-158.

${ }^{5}$ Zwraca na to uwagę Z. Klemensiewicz, Sktadnia, stylistyka, pedagogika językowa, Warszawa 1982, s. 49.
} 
$\mathrm{Z}$ jednej strony w badanym materiale ${ }^{6}$ stosunkowo łatwo jest wyodrębnić grupę zmodyfikowanych porównań utartych, gdyż istnieją punkty odniesienia: słowniki $^{7}$, znacznie szczegółowsze ustalenia językoznawców ${ }^{8}$ oraz własna świadomość językowa. $Z$ drugiej strony, pomimo braku tejże pomocy, obserwacji zostają poddane przekształcenia w obrębie porównań indywidualnych. Nie podejmuję się wykazania ewentualnych wpływów literackich, pochodzących z dzieł innych pisarzy.

\subsection{Modyfikacje porównań utartych}

W omawianym materiale obok nielicznej grupy porównań utartych występują ich odpowiedniki przekształcone, co świadczy o tym, że autor, nie rezygnując całkowicie $\mathrm{z}$ frazeologizmów, świadomie pracuje nad słowem i poszukuje nowych środków wyrazu. Ingeruje w strukturę leksykalną frazemu, rozszerzając ją o nowe elementy, wymieniając poszczególne składniki związków na inne oraz redukując niektóre stałe komponenty. Niejednokrotnie autor modyfikuje także strukturę gramatyczną części frazeologizmu w zakresie słowotwórstwa, składni i fleksji. Owe innowacje zostają w tym podrozdziale poddane bliższej obserwacji.

\subsection{Innowacje wymieniające ${ }^{9}$}

W badanym materiale najliczniejsze modyfikacje utartych związków dotyczą wymiany komponentu frazeologizmu na inny, często zbliżony znaczeniowo leksem. Na płaszczyźnie semantycznej, w schemacie porównania przekształceniu ulegają przede wszystkim: tertium comparationis i comparatum.

\footnotetext{
${ }^{6}$ Zbadany materiał obejmuje 12 dzieł J. Parandowskiego. Wyekscerpowano z nich 2548 porównań, na które składa się 75 porównań utartych, 86 porównań utartych zmodyfikowanych oraz 2387 porównań oryginalnych.

${ }^{7}$ Nowa księga przystów i wyrażeń przystowiowych polskich, red. J. Krzyżanowski, S. Świrko, t. I-IV, Warszawa 1968-1978; S. Skorupka, Stownik frazeologiczny języka polskiego, t. I-II, Warszawa 1985.

8 Por. S. Bąba, Parafrazowanie przystów i cytatów we wspótczesnej fraszce polskiej, „Poradnik Językowy” 1971, z. 8, s. 497-508; Tegoż, Modyfikacje utartych zwiazków wyrazowych we wspótczesnej fraszce polskicj, „Poradnik Językowy” 1971, z. 7, s. 444-452; Tegoż, Główne typy innowacji frazeologicznych, w: Statość i zmienność związków frazeologicznych, red. A. M. Lewicki, Lublin 1982, s. 17-25; Tegoż, Innowacje frazeologiczne wspótczesnej polszczyzny, Poznań 1989; E. Kozarzewska, Typy alternacji w statych zwiazkach frazeologicznych, „Prace Filologiczne”, t. XIX, 1969, s. 179-184; S. Skorupka, Czynniki modyfikujace znaczenie zwiazków frazeologicznych, „Roczniki Humanistyczne”, t. XXX-XXXI, 1982-1983, z. 6, s. 193-209.

"Paragrafy od 1.1 do 1.5. obejmują typy przekształceń związków w nomenklaturze S. Bąby (Gtówne typy..., op.cit.). podobnie jak w pracy M. Bury (Porównania utarte $i$ indywidualne $w$ twórczości T. Konwickiego, „Roczniki Humanistyczne”, t. HLIV z. 6, Lublin 1996, s. 45) „przyjmuje się tutaj klasyfikacje innowacji frazeologicznych $\mathrm{z}$ jednym zastrzeżeniem: porównania indywidualne nie mieszczą się $w$ typie innowacji uzupełniających. Do tej grupy Bąba zalicza bowiem tzw. indywidualizmy frazeologiczne pochodzące z języka literackiego. Zdaniem autorki, są to doraźne połączenia wyrazowe i jako takie nie wchodzą w obręb frazeologii, a więc nie mogą być traktowane jako związki wykraczające poza normę frazeologiczną".
} 


\section{a) Wymiana tertium comparationis}

(...) żótte jak miód potudnie (...) (DW 32), [stodki jak miód (SF 1/449, MIÓD), (...) stodkim jak miód mlekiem (EO 106)]

W nawiasach kwadratowych podaję frazeologizm, który stanowi bazę dla konstrukcji pośredniej między sformułowaniem oryginalnym a konwencjonalnym, czyli dla zmodyfikowanego porównania utartego. W Słowniku frazeologicznym języka polskiego pod hasłem MIÓD oraz w powieści Eros na Olimpie znajdujemy powszechnie stosowane wyrażenie słodki jak miód. Ulega ono subtelnemu przekształceniu w zakresie tertium comparationis w utworze Dwie wiosny. Tym razem cechą wspólną porównywanych elementów rzeczywistości jest barwa: żótty jak miód.

Wymianę tertium comparationis zaobserwujemy w trakcie analizy podanych fragmentów:

Okręty ich leca po morzu prędzej niż myśl (M 296), [szybki jak myśl (SF 2/290, SZYBKI), (...) w szybkich jak myśl obrotach (...) (DW 13)], [stowa] martwe jak kamienie (...) (NP 180), [twardy jak kamień (SF 1/315, KAMIEŃ)], To jest imię twojej duszy, która jest czysta jak śnieg (NP 52), [biaty jak śnieg (SF 1/98, BIAŁY), (...) biatego jak śnieg piasku (PL 250), (...) z biata jak śnieg stonina (PŻ 49)]

\section{b) Wymiana comparatum}

(...) toczyt się po piasku jak kamień (DO 85), [toczyć się jak kula, jak kłębek (SF 2/375, TOCZYĆ), toczyć się jak beczka (NKPP 3/5118, TOCZYĆ)], Powietrze stało się czyste jak diament (DW 138), [czysty jak brylant, krysztat, tza (SF 1/138, CZYSTY)], Wszyscy od niej stronili jak od ztej wróżki (WN25), [stronić od czego jak od zarazy, jak od trędowatego (SF 2/42, STRONIC), stronić od czego jak od zdechlizny, jak wilk od sieci (NKPP 3/332, STRONIĆ)], Ksiażki się boi jak żmii (P 172), [jak ognia bać się (NKPP 2/690, OGIEŃ), Bali się go jak ognia (M 144)]

Skomentuję ostatni przykład. Alternatywne comparatory ogień i żmija implikują niebezpieczeństwo. Gdyby autor zdecydował się na pierwotny frazem, wyraziłby się dość niefortunnie: Książki bat się jak ognia. Cały efekt ogromu zagrożenia, jakie powinien nieść w swej semantyce człon porównywany, mógłby ulec zachwianiu, gdyż ogień konotuje łatwopalność papieru. Zastosowane więc zmodyfikowane porównanie jest bardziej trafne. Harmonia podobieństwa książki do żmii o przejrzystej wymowie metaforycznej została zachowana, a nawet wzmocniona.

Wprowadzone w powyższych cytatach modyfikacje nie przyczyniają się do zasadniczej zmiany semantyki frazemu pierwotnego, wskazują jednakże na niezwykłą staranność autora w doborze odcieni znaczeniowych leksemów, zestawianych w jednym porównaniu. 


\subsection{Innowacje rozwijające}

Często stosowanym przez Parandowskiego zabiegiem modyfikacyjnym jest dodanie do związku utartego leksemu lub leksemów. Rozwinięciu podlegają przede wszystkim dwie grupy: comparatum i tertium comparationis.

\section{a) Rozwinięcie comparatum}

rozwinięcie comparatum o leksem: (...) zasnat jak mate dziecko (M 89), [spać jak dziecko (NKPP 3/274, SPAĆ), (...) zasną jak dziecko (M 122)], Jego próżne jęki spadały $w$ przepaść gór jak martwe kamienie (M 52), [spadać (w kogo, co ) jak kamień (SF 2/69, SPADAĆ) ]

rozwinięcie comparatum o leksemy: (...) wyrywa się z uwięzi głazów źródło, jak nie pamiętajaca o niczym, szalona dziewczyna (DW 69), [rzucać się jak szalony (SF 2/69, SZALONY)], Powracało to [pola szumiqce zbożem] jak refren dożynkowej pieśni (DW 14), [coś powraca jak refren (SF 2/8, REFREN)

Mówiąc o rozwinięciu comparatum o leksemy, należy zauważyć, że czasami są to rozwinięcia o metaforę. W poniższym przykładzie rzeczownik noc ulega personifikacji; w efekcie jeszcze bardziej uniezwykla comparandum:

(...) wtosy ciemne jak noc, która nadchodzi i zanurza w nie swoje palce (NP 383), [czarny jak noc (SF 1/150, CZARNY).

\section{b) Rozwinięcie tertium comparationis}

(...) wiersze przeźroczyste jak krysztat i tak samo geometryczne. (GS 185) [przezroczysty jak krysztat (NKPP 2/110, PRZEZROCZYSTY)] Obraz jest krótki jak błyskawica i równie olśniewajacy (DO 185), [(...) rozpostarł się krótka jak btyskawica wizja (DW 40)], [wino] byto złote jak miód i stodkie, $i$ wonne (EO 63), [stodki jak miód (SF 1/449, MIÓD)]

Osobliwą, powtarzającą się konstrukcją w przypadku rozwinięcia tertium comparationis jest jego rozbicie na element poprzedzający comparator i element umieszczony wraz ze spójnikiem za comparatum.

\subsection{Innowacje skracające}

Z twórczości Parandowskiego wyekscerpowałam tylko jedno porównanie, które powstało w wyniku uszczuplenia składu leksykalnego danej jednostki frazeologicznej. W wyrażeniu porównawczym: jak miód nie powinna wystąpić elipsa 
tertium comparationis, gdyż ma ono utartą łączliwość z różnymi leksemami ${ }^{10}$ : słodki, dobry, złocisty jak miód (SF 1/449, MIÓD) a także żótty, lepki jak miód. Jednak fragment: (...) pod szorstkim odzieniem ciało jak miód (...) (EO 97) jest klarowny, mimo opuszczenia tertium comparationis. Komunikatywność całego związku nie została osłabiona, gdyż chodzi w nim przede wszystkim o pozytywną cechę estetyczną, a nie o jeden konkretny walor zmysłowy. Tertium comparationis zamyka się w metaforycznym znaczeniu leksemu stodki, czyli przyjemny, piękny, urodziwy itp.

\subsection{Innowacje regulujące}

Niewielka ilość omawianych porównań powstała z przekształceń w zakresie słowotwórstwa, gdzie równy stopień przymiotnika ulega zdrobnieniu. Użycie hipokorystyku przyczynia się do mocniejszego zaakcentowania cechy w dwóch przykładach:

Siwiuteńki byt jak gotąb (...) (M 340), [siwy jak gotab (SF 2/117, SIWY)], Posejdon wygładzit przed nimi powierzchnię morza, że była jak stót równiutka (M 226), [równy jak stót (SF 2/221, STÓŁ)]

\subsection{Innowacje mieszane}

W licznych porównaniach uwidacznia się jednoczesna modyfikacja dwóch płaszczyzn związku: gramatycznej i leksykalnej. Zwróćmy uwagę na zmiany słowotwórcze połączone $\mathrm{z}$ innowacją rozwijającą:

[wino] jest ciemnoczerwone jak krew z tętnicy (...) (DO118), [(...) ryt się w tamtejszej czerwonej jak krew ziemi (ZN 75)].

Kolor wina został odpowiednio wycieniowany i ukonkretniony poprzez wprowadzenie przymiotnika złożonego ciemnoczerwone $\mathrm{w}$ miejsce przymiotnika prostego oraz przez dodanie do comparatum krew wyrażenia przyimkowego $z$ tętnicy. W związku z powyższą modyfikacją pojawia się pytanie: jakie czynniki motywują autora przy wyborze właśnie tego wyrażenia przyimkowego: $z$ tętnicy, skoro badania nad fizjologią człowieka uzasadniają ciemniejszy odcień krwi żylnej niż tętniczej. Nie sposób określić wiedzy autora z zakresu specjalnej dziedziny (biologii). Na podstawie jednak badanego materiału można śmiało stwierdzić dążność Parandowskiego do unikania zwrotów utartych. Znane i poświadczone przez słowniki frazeologiczne są takie związki, jak: krew pulsuje $w$ żyłach, mrozi, ścina krew w żyłach, $w$ czyichś żyłach ptynie jakaś krew (SF 1/355, KREW), żyły

\footnotetext{
${ }^{10}$ Por. Z. Leszczyński, Nad porównaniami Mickiewicza, w: Mickiewicz i Kresy. (rozprawy przedstawione na międzynarodowej sesji naukowej), red. Z. Kurzowa, Z. Cygal-Krupowa, Kraków 1997, s. 133.
} 
nabrzmiewaja nabieraja komuś krwiq (SF 2/902, ŻYŁA). W wierszu Rota M. Konopnickiej spopularyzowanym jako pieśn z muzyką F. Nowowiejskiego i śpiewanym jako hymn narodowy jest zastosowane również wyrażenie do krwi ostatniej, kropli $z \dot{z} y t$. W powszechnym użyciu rzeczownik żyła funkcjonuje znacznie częściej niż leksem tętnica ${ }^{11}$, dlatego wybór Parandowskiego pada na ten ostatni.

Porównanie Nie wiadomo skq̨d przyszedt, zdawato się, że wyróst z ziemi nagle $i$ cicho jak grzyb (DO 134) powstało na bazie utartego związku wyrastać jak grzyby po deszczu (SF 1/270, GRZYB) i różni się od niego trzema modyfikacjami: zmianą w zakresie liczby (przekształceniem liczby mnogiej rzeczownika grzyb), skróceniem comparatum (skład leksykalny frazemu został uszczuplony o wyrażenie przyimkowe po deszczu) oraz rozwinięciem comparandum (wyrażeniem przyimkowym $z$ ziemi) jak również tertium comparationis (przymiotnikami nagle $i$ cicho). Parandowski z pierwotnego związku utartego wydobywa i nasila jeden aspekt opisywanego desygnatu: nieoczekiwane pojawienie się. Odrzucenie zaś cech mnogości obiektu uwarunkowane jest bez wątpienia kontekstem.

Do metaforycznego znaczenia frazeologizmu: zawrzało jak $w$ garnku, czyli powstał zamęt, hałas, reweters (SF 1/230, GARNEK), nawiązuje konstrukcja porównawcza: Świat rozpalony od wczesnego skwaru, byt bliski wrzenia, sklepienie nieba drżało jak pokrywa garnka (DO 172) ${ }^{12}$. Efekt odświeżenia związku utartego zostaje uzyskany dzięki wymianie leksemów (zawrzało - drżało) i rozwinięciu comparatum o detal (pokrywa garnka).

Przekształcenie frazemu: ciemno jak $w$ grobie (SF 1/264, GROB) obserwujemy w następującym porównaniu: (...) okragła kaplica wygląała jak grób, rozpościerat się w niej mrok, mrok śmierci, którego nawet bogowie nie mogq unikną́ (DO 187). Dwukrotne powtórzenie rzeczownika mrok wzmacnia ciemną tonację, intensyfikuje nastrój grozy i smutku.

Interesującą grupę stanowią innowacje mieszane nie mające w pierwotnej postaci formy porównania, czyli takie, z których zostały utworzone konstrukcje porównawcze.

$\mathrm{Z}$ frazeologizmu dreszcz przebiegt (komu) po ciele (po skórze) (SF 1/757, PRZEBIEGE) powstało porównanie (...) wywotat krótkotrwały nerwowy śmiech, który przebiegt po klasie jak deszcz (ZN 81). Przekształcenie związku utartego polega przede wszystkim na wymianie leksemu dreszcz na dwa rzeczowniki spojone comparatorem (...) smiech (...) jak deszcz. Ten ostatni wywołuje powszechne skojarzenia dźwiękowe, i niejednokrotnie wyzyskuje się go w liryce jako onomatopeję. W omawianym zaś konkretnym przypadku zostaje użyty w celu opisania dźwięku wydawanego przez śmiech. Zastosowaną modyfikację można także

\footnotetext{
${ }_{11}^{11}$ Potwierdza to także brak hasła TĘTNICA w słownikach frazeologicznych.

${ }^{12}$ Porównanie osadzone jest w kontekście pędzących rydwanów.
} 
zinterpretować, przywołując charakterystyczny, przede wszystkim dla poezji, efekt zaskoczenia odbiorcy, który wywołany jest precyzyjnym doborem słów i linearnością wypowiedzi, jej trwaniem w czasie. Tę cechę artykulacji Parandowski również wykorzystuje, lokalizując $\mathrm{w}$ zakończeniu powyższego porównania niekonwencjonalny leksem deszcz. Niekonwencjonalny, gdyż poprzedzające go części mowy (przymiotniki: krótkotrwały, nerwowy oraz czasownik wraz z wyrażeniem przyimkowym przebiegt po klasie), sugerują użytkownikowi języka, który jakże często posługuje się idiomami, cechę dreszczu. Ważną sugestią jest także znikoma różnica w artykulacji obu opisywanych leksemów. Aluzja do odczucia dreszczu zaistniała jednakże w świadomości odbiorcy nie tylko dzięki pojawiającym się w porównaniu elementom składowym związku utartego, ale także przez fakt, że możliwość wywołania (w określonej sytuacji) uczucia mrowia przebiegającego po skórze jest właściwością zjawiska atmosferycznego - deszczu. Człon określający (deszcz) spełnia funkcje dźwiękonaśladowcze, a także oddaje nastrój chłodu, nieprzyjemnej atmosfery. Jest to więc przykład modyfikacji o zintensyfikowanej funkcji autotelicznej (estetycznej).

Związek utarty napoić (kogoś) octem i żótciq (SF 1/545, OCET), czyli sprawić komuś zawód, krzywdę, przykrość, stanowi podstawę porównania: $K u$ naszym zaś ustom podnosi się Polska jak gabka nasycona octem i żótciq - na ostrzu dzidy wroga (WN 43). W przytoczonym cytacie zmiany formalne łączą się z uzupełnieniem i rozwinięciem związku frazeologicznego szczegółowymi elementami z jego pierwotnego źródła - Biblii: Nałożono więc na hizop gabkę petnq octu $i$ do ust $\mathrm{Mu}$ podano ${ }^{13}$. Odwołanie się do niezawinionej męki Chrystusa potęguje bolesną sytuację naszych rodaków w czasie II wojny światowej.

Z Nowego Testamentu wywodzi się również frazeologizm: rzucić kamieniem $w$ kogo (SF 1/3116, KAMIEŃ) i jest punktem wyjścia porównania Parandowskiego: Każdq zgłoska rzucam jak kamykiem w bezdusznego olbrzyma, który pokutuje wśród tych sadów $i$ winnic (DW 133). Na uwagę zasługuje modyfikacja w zakresie słowotwórstwa, a mianowicie umieszczenie w comparatum hipokorystyku kamykiem. Autor często porównuje słowa do kamienia: [słowa] stałyby się martwe jak kamienie (NP 180), [stowa] byty ostre i zimne jak kamienie. Z żelazną konsekwencją, zgłosce jako elementowi mniejszemu niż słowo, Parandowski przypisuje bardziej adekwatny obraz kamyka, a nie kamienia. Zestawione leksemy: głoska i kamyk, które nie implikują tak wyraźnych cech bezwzględności jak słowa porównywane do kamienia, wprowadzone są w celu osłabienia semantyki pierwotnego frazemu. Potępienie bezdusznego olbrzyma, który i tak już pokutuje, rozmywa się. Ten przykład ukazuje wielką staranność Parandowskiego w pracy nad słowem, umiejętność wyzyskania detali w językowym przekazie.

${ }^{13}$ Ewangelia wg św. Jana 19, 29, Pismo Święte Nowego Testamentu, Siedlce 1985, s. 345. 


\subsection{Inne modyfikacje}

W tym paragrafie warto zwrócić uwagę na dwie osobliwości. Po pierwsze w twórczości Jana Parandowskiego liczną grupę stanowią porównania, które pod względem leksykalnym sugerują łączność z porównawczymi związkami frazeologicznymi, ale ich znaczenie uległo przekształceniu. Tego typu porównania powstają na drodze indywidualnej modyfikacji budowy formalnej związku, i różnią się od wcześniej wymienionych modyfikacji tym, że przekształcenia pociągają za sobą zmianę semantyki ${ }^{14}$.

Porównanie: Gryzł [młody uczony] jak orzechy ciemne wyrazy terminologii tacińskiej lub starofrancuskiej (PL 230) implikuje sens utartego związku: jakby orzech zgryzt czyli łatwo, sprawnie (SF 1/614). Pisarz wzbogaca go o nowe jakości we fragmencie: Tak rozmawiaty ze sobq dwie dusze (...) $w$ trzasku stów greckich, które pękaty jak tupiny orzechów, aby ukazać swój jędrny miqższ, wydobyty spod przyrostków, spójek, augmentów (NP 229). Sformułowanie zawiera nie tylko pierwotny sens związku utartego, w tym wypadku sprawności rozmowy, ale także odnosi się do wrażeń słuchowych: dźwięk artykułowanych słów zestawiony jest $\mathrm{z}$ brzmieniem wydawanym przez pękające łupiny orzechów. $\mathrm{W}$ tym cytacie mamy więc do czynienia $\mathrm{z}$ interferencją znaczeń.

Zwrot z członem porównującym: chodzić za kim, nie odstępować kogo jak cień, czyli towarzyszyć komu nieodstępnie (SF 1/143, CIEŃ), realizuje się pod względem leksykalno-semantycznym w jednym przykładzie: Odtąd szła za nim jak cień, nie opuszczała go we dnie ni w nocy (P 70). W drugim zaś przypadku jego utarte znaczenie ulega zachwianiu: Ta wieczorna pielgrzymka, która z pochodniami stawała u studni, mogła była widzieć rabek owego płaszcza, przesuwajacy się po ziemi niby cień nadchodzącej nocy (DW 59). W efekcie modyfikacji składniowej w comparandum i rozwinięcia comparatum o metaforę, człon porównywany rąbek płaszcza przyjmuje właściwości wizualne wieczornego cienia, a nie tylko jego atrybut nieodłączności od desygnatu.

Znaczenie frazeologizmu spadać, uderzać, runą́ jak grom zawiera się w przymiotnikach: nieoczekiwanie, nagle, gwałtownie (SF 1/262, GROM) i jest dość licznie wyzyskiwane w utartych porównaniach omawianej twórczości:

(...) w tym oszotomieniu spadt na nie głos jak grom - Nareszcie (ZN 67), Gtos, który się nad nimi odezwat, spadt nań jak grom (ZN 203), I wszystko spada na pana jak grom (NP 218), Sen jak grom porazit udręczone ciało (PŻ 9)

\footnotetext{
${ }^{14}$ Por. H. Pietrak-Meiser, Czeskie wyrażenia i zwroty frazeologiczne na tle porównawczym polskim, Lublin 1985, s. 116, gdzie tegotypu innowacje nazwane są parafrazami.
} 
Przesunięcie akcentów semantycznych obserwujemy zaś tylko w jednym, następującym porównaniu: Sttumiony śmiech jak daleki warkot gromu, przetoczyt się $w$ głębi szerokiej piersi korsarza (ZN 206). Konwencjonalne tertium comparationis (nagle, nieoczekiwanie) uległo wyraźnemu osłabieniu, ponieważ człon porównujący grom jest tu wyzyskany wyłącznie jako zjawisko brzmieniowe. Przymiotniki: sttumiony, daleki charakteryzują odgłos śmiechu, jego barwę, niski ton; fragment porównania: $w$ głębi szerokiej piersi tworzy doskonałą przestrzeń akustyczną, zaś czasownik przetoczyt się implikuje dłuższy czas trwania niż użyte w utartych zwrotach czasowniki: spadt, runqt, porazit.

Całkowitą zmianę znaczenia pierwotnego związku: stać jak posag, czyli nieporuszenie (SF 2/193, STAĆ) obserwujemy w daleko posuniętej modyfikacji, która wręcz eksponuje ruchliwość postaci:

Warto go było widzieć, gdy optynawszy zatokę wyskakiwat na brzeg, jak posag z brazu, obryzgany woda, stońcem, biegt po piasku, który parzyt stopy niby rozpalone żelazo, o czym on jakby nie wiedziat (ZN 192).

Cecha wspólna zestawianych desygnatów opiera się na wrażeniach wzrokowych: barwie, wspaniałej budowie fizycznej oraz „nieczułości” - odporność na ból jest atrybutem posągu i opisywanego podmiotu.

Parandowski rezygnuje także z przenośnego znaczenia utartego związku: być jak $w$ lesie - nie móc się zorientować (SF 1/375, LAS) na rzecz oddania wrażeń zmysłowych w porównaniu: Między wysokopiennymi kolumnami chodzić będziemy jak w lesie wyciętym (DW 32).

Drugą osobliwością porównań omawianej twórczości, na którą warto zwrócić uwagę, jest to, że ten sam związek frazeologiczny (bądź związki w przypadku kontaminacji ${ }^{15}$ ) leży u podstaw co najmniej dwóch porównań, w obrębie których uwidaczniają się również przekształcenia.

$\mathrm{Na}$ trzy różne, zbliżone do siebie sposoby został zmodyfikowany związek utarty: delikatny, biały jak alabaster (MS 8, ALABASTER):

Prześliczny marmur paryjski, gładki i połyskliwy jak alabaster (DW 100), Z brzegów przepaści połyskujacych jak studnie z alabastru (...) (DW 123), Darli się po przepaściach połyskujacych niby studnie o ścianach $z$ alabastru (M 237).

Skoro powyższe przekształcenia dotyczą tego samego frazeologizmu, a zasadnicza wymiana leksemów następuje w tertium comparationis z przymiotnika biały na imiesłów przymiotnikowy czynny połyskujacy, to z łatwością trzy modyfikacje można sprowadzić do wspólnego mianownika: skały (ściany przepaści, marmur) połyskujące jak alabaster, a Parandowskiego uznać za autora nowego,

${ }^{15}$ Termin wg S. Bąby, Gtówne typy innowacji, op. cit., s. 20. 
ucierającego się w jego twórczości porównania. Warto też podkreślić, że stałym elementem w omawianych przykładach jest comparandum. Jego znaczenie zamyka się w obrębie skały. Człon porównywany i porównujący są również dobrane tak, że należą do tego samego pola semantycznego i obok wyraźnie wyodrębnionego tertium comparationis zawierają dodatkową cechę wspólną (alabaster jako minerał może stanowić składnik skały). Wyraźna właściwość omawianych porównań: zestawienie obok siebie leksemów o bliskim znaczeniu przyczynia się do modyfikacji związków utartych.

Jak w wielkim stopniu modyfikacja związku utartego to dzieło własnego wysiłku pisarza, można ukazać, zestawiając obok siebie trzy następujące porównania, które są kontaminacjami trzech frazeologizmów: błyszczeć, połyskiwać jak zwierciadło, ujrzeć zobaczyć się jak w zwierciadle (bardzo dokładnie, jasno, wyraźnie), magiczne, czarodziejskie zwierciadto (SF 2/881, ZWIERCIADŁO):

Wówczas jakby w zwierciadle magicznym błyszczacych Fedriadów objawity się niknące zarysy innego świata (DW 84), Porzucitem leżak i oparty na burcie patrze $w$ migotliwa przestrzeń, $w$ nienasycone igrzysko drgań $i$ błysków $i$ jak $w$ czarnoksięskim zwierciadle, chciałbym $w$ nich odczytać, kiedy i dokad mnie poniesie to ojczyste morze (PL 277), Serce jakby przygasto, ilekroć mi się przywidywało, że nie ja patrzę na chtopca, którym kiedyś bytem, ale on z głębi swego czasu, z miękkiego gniazda ufności i spokoju, patrzy na mnie, na ten obcy pokój, na to nie przewidziane miasteczko, oglada cały ten byt o podciętych korzeniach, jakby obraz przyszłości w błyskach magicznego kryształu (WN 15).

Oto najistotniejsze modyfikacje elementów wspólnych przytoczonych porównań: wymiana rzeczowników (zwierciadło - kryształ), czasowników (objawiły się, chciałbym $w$ nich odczytać, oglada) oraz innowacja regulująca w zakresie słowotwórstwa (czarodziejski - czarnoksięski, błyszczeć - błyszczqcy - błyski).

Powyższych porównań nie sposób zakwalifikować do jednego rodzaju modyfikacji. Znajdują się one niemal na przeciwleghym biegunie związków utartych, mimo że liczne przekształcenia formalne nie pociągają za sobą zmian semantycznych.

\section{Modyfikacje porównań indywidualnych}

Głównym wyznacznikiem uznania porównania za modyfikację innego związku jest wyraźnie narzucająca się ich cecha wspólna, przede wszystkim w zakresie strukturalno-leksykalno-semantycznym. W przypadku przekształceń porównań utartych punktem wyjścia staje się frazeologizm, punktem dojścia - elementy nowatorskie. W przypadku poruszanych w tym paragrafie modyfikacji porównań oryginalnych kwestia ich badania nieco się komplikuje. Ważne jest samodzielne wyodrębnienie przez interpretatora tekstu modelu wyjściowego na podstawie cech wspólnych kilku cytatów. Pozwoli to na wgłębienie się w zjawisko 
językowe jakim jest modyfikacja, na obserwację osobliwej cechy sty Parandow skiego - przekształceń porównań własnego wytworu.

Indywidualne porównania:

Dzwony bity (...) i raz po raz silniejsze uderzenie spadato jak ciężka kropla ptynnego metalu. (NP 81), Zegar szafkowy (...) dzwoni odenwanymi uderzeniami, które spadaja w ciszę pokoju, jak mosiężne kule (ZN 6), Uderzenie zegara - samotny dźwięk - padto jak wielka ciężka kropla na jego rozdrażnienie (NP 16), Nagle odezwaty się dźwięki brzmiace tak, jakby mata szklana kulka obsuwata się po zagłębieniach zawitego mechanizmu (NP 25)

można sprowadzić do wspólnej postaci: uderzenie, dźwięk (zegara) spada (w co, na co) jak kropla, kula. Oczywiście ten schemat ulega licznym innowacjom. Najciekawszą z nich wydaje się rozwinięcie comparatum o szczegółowe cechy: rodzaj materiału, konsystencję, rozmiar desygnatu jakim jest $\mathrm{w}$ tym przypadku kula (kropla), a wszystko to w celu jak najbardziej precyzyjnego oddania i wycieniowania siły dźwięku. Poza tym można zaobserwować innowację regulującą w zakresie fleksji (zmiana liczby pojedynczej na liczbę mnogą: kula - kule) i w zakresie słowotwórstwa (zdrobnienie kulka) oraz odjęcie tradycyjnego przyrostka w czasowniku paść. Największe nowatorstwo przedstawia ostatni przykład, w którym następuje wymiana czasownika z comparandum trzech pierwszych cytatów spadać na czasownik o słabszym natężeniu tejże cechy obsuwało się i jest on zlokalizowany w comparatum.

Weźmy jeszcze pod uwagę fragmenty, w których za punkt wyjścia modyfikacji możemy przyjąć bardziej zwartą konstrukcję porównania $A$, gdyż jej cała zawartość semantyczna mieści się w comparatum przykładu $B$ :

A. (...) dat mu [demonowi] banwę ciemnobtękitna, jak u much żywiacych się ścienvem (M 169), B. (...) noc spada jak demon czarny o sinawym odcieniu tych wielkich much, które siadaja na gnijacym mięsie (DW 69).

W obrębie modyfikacji składniowej (porównanie $A$ przechodzi w comparatum porównania $B$ ) autor dokonuje kilku drobniejszych przekształceń na płaszczyźnie wymiany leksemów, służących oddaniu barwy, oraz w zakresie innowacji rozwijającej liczby mnogiej rzeczownika much.

Rozwinięcie o nowe leksemy i drobne przekształcenia składniowe trzech porównań: ramiona jak konary, piersi jak dwa puklerze, uda jak pnie drzew, obserwujemy w dwóch konstrukcjach porównawczych:

$Z$ wdzięcznym podziwem patrzyły na jego nagie ciemne ciało, ramiona do konarów dębu podobne, piersi jak dwa puklerze z brazu, uda niby pnie jakiegoś królewskiego drzewa (EO 66), Gdzie te jego barki rozłożyste, gdzie piersi jak dwa puklerze złożone, gdzie ramiona jak konary, gdzie uda niby pnie drzew, wbite w ziemię z takq moca, jakby korzeniami wroste (EO 87).

W przytoczonych przykładach części ciała ramiona, uda są porównywane do elementów roślinnych. Obserwując twórczość Parandowskiego, natrafiamy 
i na takie cytaty, w których $\mathrm{z}$ kolei składnik flory stanowi człon porównywany, a część ciała porównujący. Mamy więc do czynienia $\mathrm{z}$ wymianą w comparandum i comparatum. W powyższych przykładach pojawiło się porównanie: ramiona jak konary, poniższe zaś możemy sprowadzić do zestawienia konary jak ramiona:

(... ) pod wspaniała topolq nadwiślańska, która lśnique konary rozpinała jak ramiona wyrzucone $w$ zachwycie czy uniesieniu ku pożodze wieczornej (...) (NP 186), Rozpaczliwie powykręcane konary, zwichnięte pnie, które jednak śmiatym podchwytem, niby zgiętym $w$ tokciu ramieniem, dźwigaja nad przepaścia wciąż wzrastajacy ciężar korony (...) (DW 124).

Przykłady tego typu modyfikacji znajdujemy w następujących cytatach:

Między wysokopiennymi kolumnami chodzić będziemy jak w lesie wyciętym (DW 32), Dtugie szeregi ich obnażonych pni biegły równo, jak stupy wielonawowej światyni gotyckiej (...) (PŻ 39).

Te „obustronne” porównania możemy sprowadzić do wspólnego mianownika: kolumny (stupy) <jak> las wycięty (obnażone pnie). Omawiana modyfikacja jest możliwa wówczas, gdy cecha wspólna zestawianych desygnatów zawiera się w nich w jednakowym natężeniu.

Rozpiętość przedstawianych modyfikacji jest bardzo duża: począwszy od różnie nasilonej ingerencji autora w związki osłuchane, potoczne aż do przekształceń tego, co jest wynikiem jego samodzielnej pracy, zarówno duchowej jak i językowej. U podstaw różnego rodzaju modyfikacji na płaszczyźnie formalno-semantycznej porównania utartego leży chęć wysubtelnienia, uściślenia wyrazistości obrazu. To z kolei przyczynia się do odświeżenia frazeologizmu, wzbogacenia go o nowe jakości, uintensywnienia jego funkcji estetycznej i ekspresywnej. Przekształcenia zaś w obrębie porównań indywidualnych dowodzą, że Parandowski nie ogranicza się do wąskiego zakresu słów i budowanego $z$ nich świata, przeciwnie - fascynuje go język jako tworzywo licznych możliwości.

\section{Objaśnienie stosowanych skrótów}

1. Utwory Jana Parandowskiego:

DO - Dysk olimpijski, Warszawa 1987.

DW - Dwie wiosny, Poznań 1946.

EO - Eros na Olimpie, Warszawa 1978.

GŚ-Godzina Śródziemnomorska, Warszawa 1970.

KŻ - Król Życia, Warszawa 1972.

M - Mitologia. Wierzenia i podania Greków i Rzymian. Warszawa 1962.

NP - Niebo w Ptomieniach, Warszawa 1978.

P - Petrarka, Warszawa 1975.

PL - Podróże literackie, Wrocław 1958. 
PŻ - Powrót do życia, Warszawa 1971.

WN - Wrześniowa noc, Warszawa 1975.

ZN - Złota nić, Kraków 1988.

2. Słowniki:

MS - Mały słownik języka polskiego, PWN, Warszawa 1999.

NKPP - Nowa księga przysłów $i$ wyrażeń przysłowiowych polskich, red. J. Krzyżanowski, S. Swirko, t. I-IV, Warszawa 1968-1978.

SF - S. Skorupka, Słownik frazeologiczny jezzyka polskiego, t. I-II, Warszawa 1985.

\title{
Maria Joka
}

\section{MODIFICATION OF WIDE ACCEPTED AND INDIVIDUAL COMPARISONS IN JAN PARANDOWSKI'S OUTPUT}

\begin{abstract}
Summary
On the basis of analyzed material I claim that Jan Parandowski uses modification of a wide accepted and individual comparisons in his output. Author interferes in various ways into the lexical structure of phraseologies he enlarges it with new constituents (developing innovations), distinguishes particular elements of connections (exchanging innovations) and reduces some permanent components (shortening innovations). Author modifies grammatical structure of a part of phraseology's over the word building range, also syntax and inflexion, more than once (adjusting innovations). Jan Parandowski has a fascination for language as a material of many alternatives he doesn't recall his own utterances automatically and his transformations in a range of individual comparisons prove that certainly.
\end{abstract}

